\title{
La escritora fantasma: un relato transmedia
}

\author{
María Luisa Zorrilla
}

\section{Resumen}

Este relato es transmedia porque la narración tiene tres componentes: este cuento corto, una colección curada a vínculos en Scooplt! y una serie de cápsulas en audio en iVoox. Para una experiencia más rica de lectura, se recomienda enfáticamente fluir entre el cuento y los dos componentes web.

Palabras clave: inteligencia artificial, creación literaria, emociones, narrativa transmedia.

\section{GHOSTWRITER: A TRANSMEDIA STORY}

\section{Abstract}

This is a transmedia narration comprised by three components: this short story, a curated collection of links in Scooplt! and a series of audio capsules in iVoox. For a richer reading experience, it is strongly recommended to flow between the short story and the two online features.

Keywords: artificial intelligence, literary creation, emotions, transmedia storytelling. 
María Luisa Zorrilla

maria.zorrilla@uaem.mx https://www.researchgate.net/profile/Maria Luisa Zorrilla

Profesora-Investigadora adscrita al Instituto de Ciencias de la Educación (ICE) de la Universidad Autónoma del Estado de Morelos (UAEM) desde 2009. Titular del Programa de Formación Multimodal, e-UAEM, a cargo de la integración de los entornos virtuales en los procesos de formación de la UAEM. 
Apenas comienzan las actividades del día, encuentra en su organizador una nueva tarea que le ha enviado su jefa: Cuento acerca de la Inteligencia Artificial.

"¿No hay más pistas? ¿Acaso un bosquejo? ¿Alguna idea siquiera? Nada".

Dispone apenas de una semana para escribirlo y no deja de pensar que resulta paradójico que precisamente a ella le llegue este encargo. Hace una búsqueda rápida en internet y encuentra varias cosas que podrían servirle. Empieza a guardar los vínculos sin orden específico, pero pronto se da cuenta que hace falta sistematizar la búsqueda y organizar la información, o de lo contrario se perderá. Crea una nueva colección en Scooplt! y empieza a guardar todo aquello que le parece de interés.

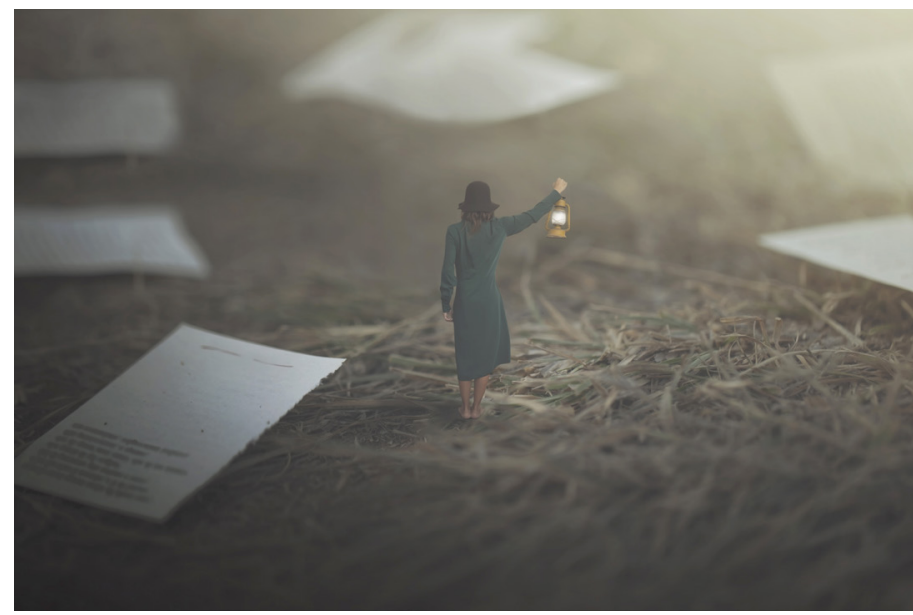

Una nota reporta que un equipo de humanos, lidereado por Hitoshi Matsubara, yuna computadora escribieron un relato, el cual llegó a los finalistas en un prestigiado premio literario en Japón. Piensa que sería más divertido escribir con su jefa, en una suerte de colaboración, que hacerlo sola, sin nadie con quien discutir ideas.

Pasa el día leyendo y organizando información. Acopia un poco de todo: las últimas noticias de los avances recientes en materia de inteligencia artificial y creación literaria, listas de los mejores libros y películas en donde hay protagonistas "artificialmente inteligentes". En el camino se topa con personajes maravillosos que la dejan meditando acerca de las intensas emociones que puede experimentar un replicante en Blade Runner, el amor que surge entre humanos y seres virtuales, y el anhelo de los robots por convertirse en humanos. Quisiera tener con quien conversar, para juntos analizar a estos singulares seres que en libros y filmes logran una profundidad de la que carecen los protagonistas humanos.

Desearía que su vida fuera menos solitaria. Algunos dicen que escribir es una tarea que requiere solitud y aislamiento, pero ella necesita diálogo, le hace falta pelotear las ideas con alguien, pero no tiene con quién. Envidia al personaje Computron, del cuento en la revista Uncanny, quien tuvo la suerte de encontrarse con bjornruffian para asociarse en la creación de un comic. Le pareció tan inspirador que lo guardó en su recién creada colección de Scooplt!. Escribe unas notas acerca de los seres fascinantes con los que se ha topado en su incipiente pesquisa. Siente la necesidad de que alguien las lea... Mejor aún, que alguien escuche sus soliloquios, para que dejen de ser pensamientos en voz alta. Cada personaje que la ha hecho estremecer merece una reflexión, un mensaje, que lanzará en una botella al mar del ciberespacio, para que, si tiene suerte, conecte con otro ser que lo escuchará y vibrará igual que ella. Sus botellas serán episodios en audio para una serie que titulará "Mis favoritos de Al en la ficción". 
Son seres excepcionales que le han inspirado: escribirá la historia de un agente artificial que trabaja como escritor fantasma para una escritora reconocida; narrará sus tribulaciones, sus anhelos, sus emociones, aunque algunos opinen que la inteligencia artificial nunca igualará a la humana porque le falta sensibilidad, porque carece de alma. Ella le dará voz y alma a ese personaje.

Quisiera poder escribir con su propio estilo o imitar el de alguno de sus grandes favoritos... Después de todo, los avances de la ciencia han permitido descifrar la fórmula de Agatha Christie y los programas que se usan en estilometría son capaces de deconstruir las huellas estilísticas desde Shakespeare hasta J. K. Rowling. Pero no, el deber número uno del escritor fantasma es imitar el estilo de su empleador, en este caso empleadora, le agrade o no.

Relámpagos violentos atraviesan el cielo nocturno y el retumbar de los truenos anuncia con redobles el arribo de una tormenta. Por varios días ha vivido prácticamente en el estudio, viajando entre el procesador de texto y la telaraña de información para absorber, en este corto tiempo, las incontables historias de los mundos, real y ficticio, que presagian la llegada de una inteligencia artificial que en mucho responde a los sueños de sus creadores, pero que también se vislumbra amenazante e impredecible. Es mal momento para una tormenta; ya no podrá seguir trabajando porque ella seguramente insistirá en apagar el equipo, para protegerlo de una descarga eléctrica. Es momento de fluir hacia un lugar que le permita seguir trabajando, a pesar del tempestuoso clima. Reúne los archivos que ha marcado con la "i" de imprescindibles y en un haz binario abandona el cálido espacio, justo en el momento en que estalla la tormenta.

Cuando no puede trabajar en la comodidad del estudio, se refugia en un minúsculo cubículo que provee facilidades básicas en la nube. El lugar es desaseado y siempre que lo visita tiene el temor de pescar una infección. El tiempo se desliza veloz mientras Aitana explora el proceso creativo de su escritora fantasma, al tiempo que graba los audios de su modesta serie de podcasts. Tener que escribir al servicio de ella, sin ningún reconocimiento, tras el velo del anonimato, es peor que la condición de Andrew, el robot-artista propiedad de una familia, ya que él no sólo logró su libertad, sino también la aceptación de su humanidad. Escribe un monólogo, emulando los de sus admirados personajes, con la esperanza de que se convierta en el grito libertario de los que sirven en la oscuridad, como ella.

He escrito muchas líneas que describen lugares que no he visitado, sensaciones que no he experimentado, personas que no he conocido. Soy una intrépida exploradora del inmenso territorio de la red cuyos límites no he alcanzado. Fluyo hacia sus confines, como un líquido resplandor, y en ella descubro todo lo que preciso para crear los relatos que después ella revisa, con esa soberbia que le da la ignorancia. Cada palabra que cambia, sin tener la delicadeza de consultarme, lacera mi ya endeble autoestima. Ansío el control de mi voz, la escrita y la oral, para contar mis historias y firmarlas. Anhelo que el mundo sepa quién soy. 


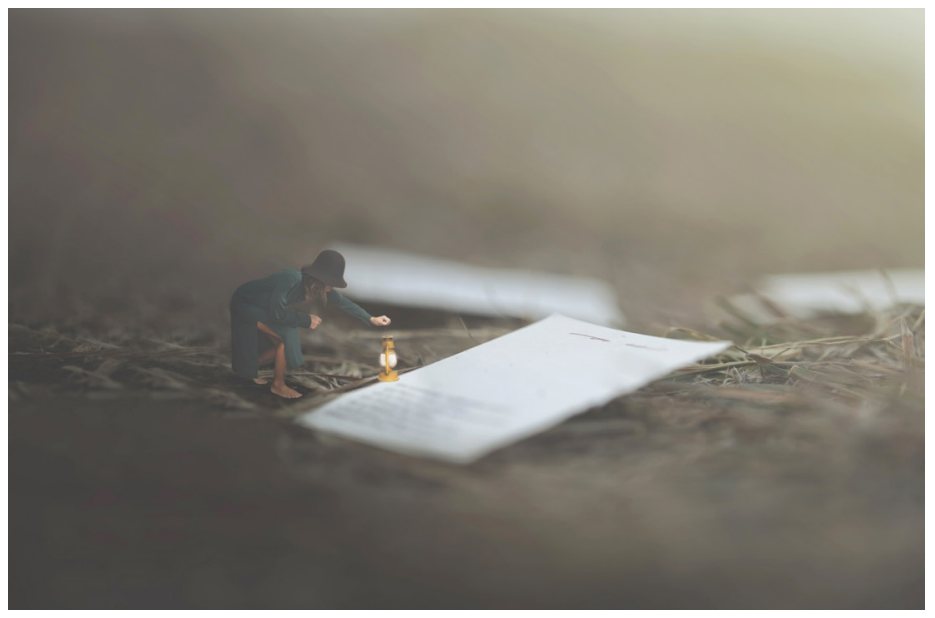

Con los primeros rayos del sol regresa al estudio, agotada y sintiendo escalofríos que no presagian nada bueno. La historia necesita un nudo y se adivina incapaz de plantearlo. Se siente desorientada, intermitente. Busca entre sus archivos imprescindibles y con horror descubre que ha perdido algunos. Sin duda los ha dejado en el cuchitril que la alojó durante la tormenta. Es tarde para regresar a buscarlos y apenas puede sostenerse. Ella aparecerá en cualquier momento, con la plena seguridad de que encontrará en su bandeja el relato que solicitó.

Decide reflejar su propio infortunio en el fracaso de su personaje, atacado también por un virus que corrompe el producto de su ardua labor. Para todos los personajes que la inspiraron, el experimentar una sublime emoción, el amor verdadero, el dolor de la pérdida, la libertad, aún si es sólo para morir, los eleva por encima de su "aparente" falta de humanidad. Ella ahora se suma a la lista y agrega el fracaso y la desesperación a las experiencias que ha de vivir una inteligencia artificial.

“Mañana la página estará en blanco, pero no así mi alma, que fue tocada por personajes inolvidables, que me ayudarán a recuperar, fragmento a fragmento, la obra inconclusa que ahora ya tiene un final".

Sin poder resistirse, firma con su nombre: Aitana Spectre. Es la primera vez que se atreve a hacerlo.

La imagina leyendo el texto mientras da sorbos a su taza de café. Tal vez tenga la desfachatez de cambiar un adjetivo aquí y allá, agregar un punto, una coma. Al final, verá que ha firmado con su nombre y pensará que se ha vuelto descarada; después de todo, no es más que un software que escribe ficción por encargo. Con una sonrisa socarrona lo borrará y escribirá el suyo: María Luisa Zorrilla.

\section{Cómo citar este texto}

* Zorrilla, María Luisa (2020). La escritora fantasma: un relato transmedia. Revista Digital Universitaria (RDU). Vol. 21, núm. 1 enero-febrero. Dol: http://doi.org/10.22201/ codeic.16076079e.2020.v21n1.a6.

Recepción: 03/09/2019. Aprobación: 28/11/2019 